\title{
A Study of Intercropping Model of Maize and Soybean in Melaleuca leucadendra Agroforestry
}

\author{
Ardian Elonard \\ Department of Agribusiness Horticulture \\ Politeknik Wilmar Bisnis Indonesia \\ Sumatra Utara, Indonesia \\ elonard.4rdian@gmail.com
}

\author{
Natalia Lusianingsih \\ Department of Agribusiness Horticulture \\ Politeknik Wilmar Bisnis Indonesia \\ Sumatra Utara, Indonesia
}

\begin{abstract}
Enhancing agricultural production is important as an effort to support food security. The main commodities need to be improved are crops, namely maize and soybeans which become an important element in agricultural system. A low production of crop and lack of product availability need to be improved through alternative ways and new technology. One of them is the application of intercropping on agroforestry systems, where the cultivation pattern is intended to increase species diversity in non-conventional ecosystems and site-specific land-based uses. The experiment was conducted by Strip-Plot design with two factors, namely plant spacing and land zone. The data was processed using three analyses, ANOVA test followed by Duncan Multiple Range Test (DMRT) with 5\% confidence level, and Optimization test as the determinant of optimum yield. The results showed that the application of intercropping in agroforestry system can be recommended at a plant spacing of $70 \times 20 \mathrm{~cm}$, both in land zone 1 and land zone two based on the aspect of Land Equivalent Ratio and Area Time Equivalent Ratio.
\end{abstract} spacing

Keywords- agroforestry, intercropping, land zone, plant

\section{INTRODUCTION}

Food security is the main target for achieving sustainable agriculture. One of the main factors to support the achievement of a food security is an increase in agricultural production. In line with this, it is necessary to innovate in conducting the cultivation system, so that an increase in agricultural production can be achieved. At present the main problem in increasing agricultural production is the reduction in agricultural area. According to the Ministry of Agriculture, the conversion of land from agricultural sector to non-agricultural sector reaches 47 thousand hectares by year. Referring to this, there needs to be a way to get around the availability of agricultural area as an effort to increase agricultural production. Another thing that needs to be considered is the priority of agricultural commodities, wherever crops become commodities that are considered to be improved. Maize and soybeans are crops that have an important role in food security. The need for these two plants is very high in Indonesia, which averagely reaches 6.49 million tons by year for maize and 3.7 million tons for soybeans [1].

One solution to dealing with these two problems is sitespecific cultivation as an optimization step for agricultural area. The use of land available among forest plants is an alternative that can be done for the cultivation of seasonal crops, where the combination of the two forms a system, namely agroforestry. This system is one of the land management systems that can be used as a solution to increase both land productivity and agricultural production. According to [2], tree components in agroforestry systems increase the amount of $\mathrm{C}$ stored in the soil which can play a role in the growth of plants underneath, so indications for use as seasonal crops have good potential. A study showed that the agroforestry system of albasia has a significant effect on an increasing number in pods of soybean [3].

Agroforestry systems are an opportunity that can be used as a way to increase agricultural production. One of them is the application of intercropping in agroforestry systems, where this cropping pattern is intended to increase species diversity in non-conventional ecosystems and site-specific land-based uses. This system also can provide optimum results in terms of production because it is composed of several commodities, so that there is a sustainable system [4]. Through this pattern, a research was carried out with an aim to see the ability to grow and the results of the agricultural component and formulate appropriate strategic recommendations in agroforestry systems.

\section{METHODS}

The experiment was conducted in KPH Gunung Kidul, Yogyakarta in November 2014 until March 2015. The research was carried out using a field experiment method consisting of two factors and was designed using a strip plot. The first factor was the main plot in the form of land zone and the second factor as the sub plot was plant spacing. The main plot was in the form of a land zone consisting of 2 levels, namely Zone 1 located in the position of the field that was $0-1 \mathrm{~m}$ from the stand position (Z1); Zone 2 was located in the position of the processing field that was $>1 \mathrm{~m}$ from the stand position (Z2). Subplots were maize spacing consisting of 3 levels, namely: $50 \mathrm{~cm} \times 20 \mathrm{~cm}(\mathrm{~J} 1), 70 \mathrm{~cm} \mathrm{x}$ $20 \mathrm{~cm}(\mathrm{~J} 2)$ and $90 \mathrm{~cm} \times 20 \mathrm{~cm}(\mathrm{~J} 3) .40 \times 25 \mathrm{~cm}$ soybean spacing was adjusted to the spacing of maize. Monoculture in the Melaleuca leucadendra system was used as a control using maize spacing of monoculture (MJ) $70 \times 20 \mathrm{~cm}$, and soybean spacing (MK) $40 \times 25$.

The data was processed using three analyses, ANOVA test followed by Duncan Multiple Range Test (DMRT) with $5 \%$ confidence level, and optimization test as determinant of optimum yield. 


\section{RESULT AND DISCUSSION}

\section{A. Yield and Yield Component of Maize}

The analysis of variance indicated no interaction between the plant spacing with land zone on yield and yield component. Treatment plant spacing showed no significant difference in all parameters for yield and yield components, as well as land zone.

Table 1. Yield and yield component of maize

\begin{tabular}{|c|c|c|c|c|c|c|}
\hline \multirow[b]{2}{*}{ Treatment } & \multicolumn{6}{|c|}{ Variable } \\
\hline & $\begin{array}{c}\text { Ear } \\
\text { length } \\
(\mathrm{cm})\end{array}$ & $\begin{array}{c}\text { Ear } \\
\text { diame } \\
\text { ter } \\
(\mathrm{cm})\end{array}$ & $\begin{array}{c}\text { Numbe } \\
\text { r of } \\
\text { rows } \\
\text { (grain) }\end{array}$ & $\begin{array}{c}\text { Amount } \\
\text { of seed } \\
\text { by ear } \\
\text { (grain) }\end{array}$ & $\begin{array}{c}\text { Dry } \\
\text { weig } \\
\text { ht } \\
(g)\end{array}$ & $\begin{array}{c}\text { Yield } \\
(t / h a \\
\quad)\end{array}$ \\
\hline \multirow{2}{*}{$50 \times 20 \mathrm{~cm}$} & 13.93 & 44.53 & \multirow{2}{*}{$14.67 \mathrm{a}$} & \multirow{2}{*}{$369.2 \mathrm{a}$} & 22.8 & 2.88 \\
\hline & & & & & $3 \mathrm{a}$ & \\
\hline \multirow{2}{*}{$70 \times 20 \mathrm{~cm}$} & 15.10 & 45.95 & \multirow{2}{*}{$14.83 \mathrm{a}$} & \multirow{2}{*}{$444.1 \mathrm{a}$} & 23.0 & 2.96 \\
\hline & & $\mathrm{a}$ & & & $7 \mathrm{a}$ & $\mathrm{a}$ \\
\hline \multirow{2}{*}{$90 \times 20 \mathrm{~cm}$} & 14.55 & 46.05 & \multirow{2}{*}{$15.67 \mathrm{a}$} & \multirow{2}{*}{$430.4 \mathrm{a}$} & 23.3 & 2.93 \\
\hline & $\mathrm{a}$ & $\mathrm{a}$ & & & $5 \mathrm{a}$ & $\mathrm{a}$ \\
\hline \multirow{2}{*}{ Zone 1} & 14.47 & 45.40 & \multirow{2}{*}{$14.78 \mathrm{a}$} & \multirow{2}{*}{$411.4 \mathrm{a}$} & 23.4 & 2.96 \\
\hline & $\mathrm{a}$ & $\mathrm{a}$ & & & $1 \mathrm{a}$ & $\mathrm{a}$ \\
\hline \multirow{2}{*}{ Zone 2} & 14.57 & 45.62 & \multirow{2}{*}{$15.33 \mathrm{a}$} & \multirow{2}{*}{$417.8 \mathrm{a}$} & 22.7 & 2.89 \\
\hline & $\mathrm{a}$ & $\mathrm{a}$ & & & $6 \mathrm{a}$ & $\mathrm{a}$ \\
\hline Interaction & $(-)$ & $(-)$ & $(-)$ & $(-)$ & $(-)$ & $(-)$ \\
\hline $\mathrm{CV}$ & 4.77 & 3.18 & 5.96 & 9.23 & 7.11 & 7.04 \\
\hline
\end{tabular}

According to the data in Table 1, the treatment of plant spacing $70 \times 20 \mathrm{~cm}$ has relatively the highest percentage compared to the planting distance of $50 \times 20 \mathrm{~cm}$ and $90 \mathrm{x}$ $20 \mathrm{~cm}$. It is suspected that the plant spacing of $70 \times 20 \mathrm{~cm}$ is more effective in utilizing resources both above ground and underground, so that competition between plants can be suppressed. According to [5], maize highly needs sunlight, especially light intensity. Land zone showed that zone two has a relatively higher value on the parameters of ear length, ear diameter, number of rows, and number of seeds by ear, in terms of dry weight and yield, zone two is higher. It is foreseeable at the time of ear formation that zone two has high humidity, but less intensity of light, ear consequently has less than the maximum grain and the impact on dry weight and yield.

\section{B. Yield and Yield Component of Soybean}

The highest number of pods by plant was found in the plant spacing of $70 \times 20 \mathrm{~cm}$. This is allegedly related to soybean plants belonging to the $\mathrm{C} 3$ plant group, where in general they do not need full light because in full light they will inhibit dry material production. A more optimal light intensity and a level of competition that is still within the threshold makes pod formation with $70 \times 20 \mathrm{~cm}$ maize spacing more optimal.

The parameters of dry weight were not aligned with the parameters of the number of pods by plant which showed no significant difference. This is related to the use of the same soybean varieties, so that on average the seeds have the same weight. The same thing was also shown by the parameters of yield, where the treatment of spacing and fields did not show any significant differences.
Table 2. Yield and yield component of soybean

\begin{tabular}{lllll}
\hline & \multicolumn{4}{c}{ Variable } \\
\cline { 2 - 5 } Treatment & $\begin{array}{c}\text { Number of } \\
\text { Pods } \\
\text { (piece) }\end{array}$ & $\begin{array}{c}\text { Number of } \\
\text { Seeds by } \\
\text { Pod } \\
\text { (grain) }\end{array}$ & $\begin{array}{c}\text { Dry Weight } \\
(\mathrm{g})\end{array}$ & $\begin{array}{c}\text { Yield } \\
(\text { t/ha })\end{array}$ \\
\hline $50 \times 20 \mathrm{~cm}$ & $28.10 \mathrm{~b}$ & $2.00 \mathrm{a}$ & $8.47 \mathrm{a}$ & $0.30 \mathrm{a}$ \\
$70 \times 20 \mathrm{~cm}$ & $45.40 \mathrm{a}$ & $2.00 \mathrm{a}$ & $8.34 \mathrm{a}$ & $0.49 \mathrm{a}$ \\
$90 \times 20 \mathrm{~cm}$ & $29.51 \mathrm{~b}$ & $2.00 \mathrm{a}$ & $8.14 \mathrm{a}$ & $0.29 \mathrm{a}$ \\
\hline Zone 1 & $31.93 \mathrm{a}$ & $2.00 \mathrm{a}$ & $8.22 \mathrm{a}$ & $0.33 \mathrm{a}$ \\
Zone 2 & $36.74 \mathrm{a}$ & $2.00 \mathrm{a}$ & $8.42 \mathrm{a}$ & $0.39 \mathrm{a}$ \\
\hline Interaction & $(-)$ & $(-)$ & $(-)$ & $(-)$ \\
\hline CV & 23.65 & 0 & 6.62 & 30.13 \\
\hline
\end{tabular}

\section{Land Equivalent Ratio (LER) and Area Time Equivalent Ratio (ATER)}

LER values range between $0-1$, where if LER value $>1$ then the intercropping system has a higher land use efficiency [6], in addition, the ATER value has the same criteria as LER, where ATER $>1$ shows that with a monoculture system it takes longer to match the results of the intercropping system, so that through the intercropping system there is an increase in land use time.

$\underline{\text { Table 3. Land equivalent ratio and area time equivalent ratio }}$

\begin{tabular}{|c|c|c|}
\hline \multirow{2}{*}{ Treatment } & \multicolumn{2}{|c|}{ Variable } \\
\hline & LER & ATER \\
\hline $50 \times 20 \mathrm{~cm}$ & $1.49 \mathrm{a}$ & $1.40 \mathrm{a}$ \\
\hline $70 \times 20 \mathrm{~cm}$ & $1.77 \mathrm{a}$ & $1.63 \mathrm{a}$ \\
\hline $90 \times 20 \mathrm{~cm}$ & $1.52 \mathrm{a}$ & $1.43 \mathrm{a}$ \\
\hline Zone 1 & $1.62 \mathrm{a}$ & $1.53 \mathrm{a}$ \\
\hline Zone 2 & $1.55 \mathrm{a}$ & $1.44 \mathrm{a}$ \\
\hline Interaction & $(-)$ & $(-)$ \\
\hline $\mathrm{CV}$ & 6.65 & 5.77 \\
\hline
\end{tabular}

Based on the data in Table 3, all the treatments do not show any significant differences. Both LER and ATER values are above 1 , which means that intercropping systems have a higher use efficiency than monoculture systems.

Table 4. Estimation of maize and soybean yield at various plant spacing in zone 1

\begin{tabular}{|c|c|c|c|c|c|}
\hline \multicolumn{6}{|c|}{ Variable } \\
\hline $\begin{array}{l}\text { Estimat } \\
\text { ed Plant } \\
\text { Spacing } \\
(\mathrm{cm})\end{array}$ & $\begin{array}{l}\text { Estimat } \\
\text { ion of } \\
\text { Maize } \\
\text { Product } \\
\text { ion }(t)\end{array}$ & $\begin{array}{l}\text { Estimat } \\
\text { ion of } \\
\text { Soybea } \\
n \\
\text { Product } \\
\text { ion }(t) \\
\end{array}$ & $\begin{array}{l}\text { Estimation } \\
\text { of Maize } \\
\text { Yield } \\
\text { (IDR) }\end{array}$ & $\begin{array}{l}\text { Estimation } \\
\text { of } \\
\text { Soybean } \\
\text { Yield } \\
(\text { IDR }) \\
\end{array}$ & $\begin{array}{l}\text { Economic } \\
\text { Estimatio } \\
\boldsymbol{n} \\
(\text { IDR })\end{array}$ \\
\hline 62.95 & 2.06 & $0.26^{*}$ & $5,562,000$ & $\begin{array}{l}1,742,000 \\
*\end{array}$ & $\begin{array}{l}5,217,657 \\
*\end{array}$ \\
\hline 63.91 & 2.08 & 0.25 & $5,616,000$ & $1,675,000$ & $5,172,840$ \\
\hline 64.86 & $2.09 *$ & 0.24 & $\begin{array}{l}5,643,000 \\
*\end{array}$ & $1,608,000$ & $5,101,354$ \\
\hline 65.99 & 2.08 & 0.22 & $5,616,000$ & $1,474,000$ & $4,902,903$ \\
\hline 67.47 & 2.07 & 0.21 & $5,589,000$ & $1,407,000$ & $4,759,851$ \\
\hline 69.31 & 2.06 & 0.20 & $5,562,000$ & $1,340,000$ & $4,604,869$ \\
\hline 71.54 & 2.05 & 0.18 & $5,535,000$ & $1,206,000$ & $4,369,960$ \\
\hline 74.14 & 2.04 & 0.17 & $5,508,000$ & $1,139,000$ & $4,189,789$ \\
\hline 77.13 & 2.03 & 0.16 & $5,481,000$ & $1,072,000$ & $3,996,691$ \\
\hline 80.50 & 2.02 & 0.15 & $5,454,000$ & $1,005,000$ & $3,791,000$ \\
\hline 84.24 & 2.01 & 0.14 & $5,427,000$ & 938,000 & $3,573,046$ \\
\hline
\end{tabular}




\section{Optimization of Maize and Soybean Based on Plant}

Spacing in Zone 1 and Zone 2

The data showed that the estimated spacing between rows of $62.95 \mathrm{~cm}$ in zone 1 has the highest estimated economic yield of maize and soybeans, whereas in zone 2, the estimated spacing between rows $69.62 \mathrm{~cm}$ has the highest estimated economic yield of maize and soybeans.

Table 5. Estimation of maize and soybean yield at various plant spacing in zone 2

\begin{tabular}{llllll}
\hline \multicolumn{5}{c}{ Variable } \\
\hline $\begin{array}{l}\text { Estimat } \\
\text { ed } \\
\text { Plant } \\
\text { Spacin } \\
\text { (cm) }\end{array}$ & $\begin{array}{l}\text { Estimat } \\
\text { ion of } \\
\text { Maize } \\
\text { Product } \\
\text { ion }(\boldsymbol{t})\end{array}$ & $\begin{array}{l}\text { Estimat } \\
\text { ion of } \\
\text { Soybea } \\
\text { n Product } \\
\text { ion }(\boldsymbol{t})\end{array}$ & $\begin{array}{l}\text { Estimation } \\
\text { of Maize } \\
\text { Yield } \\
(\text { IDR })\end{array}$ & $\begin{array}{l}\text { Estimation } \\
\text { of } \\
\text { Soybean } \\
\text { Yield } \\
(\text { IDR })\end{array}$ & $\begin{array}{l}\text { Economic } \\
\text { Estimation } \\
(\text { IDR })\end{array}$ \\
\hline 69.62 & $2.06^{*}$ & 0.41 & $\begin{array}{l}5,562,000 \\
*\end{array}$ & $2,747,000$ & $\begin{array}{l}6,001,594 \\
*\end{array}$ \\
\hline 75.91 & 2.03 & 0.40 & $5,481,000$ & $2,680,000$ & $5,645,126$ \\
\hline 82.71 & 2.00 & 0.40 & $5,400,000$ & $2,680,000$ & $5,338,754$ \\
\hline 90.27 & 1.97 & 0.41 & $5,319,000$ & $2,747,000$ & $5,074,194$ \\
\hline 98.71 & 1.95 & 0.41 & $5,265,000$ & $2,747,000$ & $4,740,469$ \\
\hline 108.08 & 1.92 & 0.41 & $5,184,000$ & $2,747,000$ & $4,348,920$ \\
\hline 118.41 & 1.89 & 0.42 & $5,103,000$ & $2,814,000$ & $3,992,554$ \\
\hline 129.72 & 1.86 & 0.43 & $5,022,000$ & $2,881,000$ & $3,603,709$ \\
\hline 142.01 & 1.83 & 0.43 & $4,941,000$ & $2,881,000$ & $3,115,383$ \\
\hline 155.29 & 1.81 & $0.44 *$ & $4,887,000$ & $\begin{array}{l}2,948,000 \\
*\end{array}$ & $2,688,246$ \\
\hline 169.57 & 1.78 & $0.44 *$ & $4,806,000$ & $\begin{array}{l}2,948,000 \\
*\end{array}$ & $2,133,966$ \\
\hline
\end{tabular}

Note: *highest estimation

The economic results of maize and soybean in zone 1 and zone 2 are found in spacing between rows of $62.95 \mathrm{~cm}$ and $69.62 \mathrm{~cm}$ respectively. Plant spacing between rows in zone 1 , which is slightly denser than that in zone 2 , shows optimum results. It is suspected that there are slight differences in the availability of resources in each zone. The indication is that in zone 1 the available resources are better compared to those in zone 2, so that with a denser spacing between rows the results can still be maintained.

\section{IV.CONCLUSION}

Based on these results, it can be seen that (1) Plant spacing of $70 \times 20 \mathrm{~cm}$ becomes the best recommendation, (2) The best economic estimation is at plant spacing of $70 \mathrm{x}$ $20 \mathrm{~cm}$, (3) Intercropping technology based on Melaleuca leucadendra agroforestry has good results and efficiency that can be maintained.

\section{ACKNOWLEDGEMENTS}

The authors thank the funders, mentors, and other parties who helped implement this research. Hopefully this research could be a form of work that is useful for agricultural progress in Indonesia.

\section{REFERENCES}

[1] C. B. o. Statistic, "Rice, Maize, and Soybean Production," 2013. [Online]. http://www.bps.go.id/brs_file/aram_01jul13.pdf.

Available:

[2] P. Johu, Y. Sugito and B. Guritno, "Pengaruh Populasi dan Jumlah Tanaman Per Lubang Tanaman Jagung (Zea Mays L.) dalam Pola Tumpangsari dengan Kacang Buncis (Phaseolus Vulgaris L.) Terhadap Pertumbuhan dan Hasil Tanaman," Agrivita, vol. 1, no. 24, pp. 17-24, 2012.

[3] E. Kursten, "Fuelwood in Agroforestry System for Sustainable Land use and CO2 Mitigation," Ecol Eng, vol. 16, pp. 69-72, 2011.

[4] R. B. Prasad and R. M. Brook, "Effect of Varying Maize Densities on Intercropped Maize and Soybean in Nepal," Expl. Agric, vol. 41, pp. 365-382, 2005.

[5] R. Riefna, S. Titin and Y. T. Setyono, "Respon Dua Varietas Kedelai (Glycine Max (L.) Merr) Terhadap Perbedaan Intensitas Cahaya Pada Sistem Agroforestry Berbasis Sengon," Jurnal Produksi Tanaman," Jurnal Produksi Tanaman, vol. 5, pp. 15611569, 2017.

[6] L. Lie, J. H. Sun, F.S. Zhang, X. Y. Li, Z. Rengel and S.C. Yang, "Wheat/Maize or Wheat/Soybean Strip Intercropping. Yield Advantage and Interspesific Interaction on Nutrients," Field Crops, vol. 71, pp. 123-137, 2001. 